Indo. J. Chem. Res., 2017, 5(1), 7-11

\title{
ADSORPSI Hg(II) MENGGUNAKAN Sargassum crassifolium DENGAN ADANYA Pb(II), Cu(II) DAN Fe(II)
}

\author{
Adsorption of $\mathrm{Hg}(\mathrm{II})$ by Using Sargassum crassifolium With \\ Presence of $\mathrm{Pb}(\mathrm{II}), \mathrm{Cu}(\mathrm{II})$ And $\mathrm{Fe}(\mathrm{II})$
}

\author{
Nurhadini $^{1}{ }^{*}$, Imelda H. Silalahi ${ }^{2}$ \\ ${ }^{1}$ Chemistry Department, Faculty of Engineering Bangka Belitung University, \\ Jl. Kampus Peradaban, Bangka 33172 \\ ${ }^{2}$ Chemistry Department, Faculty of Mathematic and Natural Sciences, Tanjungpura University, \\ Jl. Prof. Hadari Nawawi, Pontianak 78132-Indonesia \\ *Corresponding author, e-mail: nurhadini@ubb.ac.id
}

Received: October 2016 Published: January 2017

\begin{abstract}
Amalgamation use mercury in mining process especially small-scale gold mining and it has been impacted on mercury contamination in environment. Mercury is one of heavy metal that toxic and can accumulate in water, soil and organism. Adsorption method is one of alternative option that effective to remove heavy metal. This method depends on adsorbent type, $\mathrm{pH}$, adsorbent composition with metal or presence of several metal ions. Beside mercury, wastewater of mining gold have another metal ions such as $\mathrm{Pb}$ (II), $\mathrm{Cu}$ (II) dan $\mathrm{Fe}$ (II) can be found by human activity or naturally present. This research aim is to study effect of $\mathrm{Pb}$ (II), $\mathrm{Cu}(\mathrm{II})$, and $\mathrm{Fe}$ (II) in $\mathrm{Hg}$ (II) adsorption by using Sargassum crassofolium adsorbent. Research stages are adsorbent activation and mercury adsorption on binary and ternary system respectively in equimass amount of metals ion and equimolar amounts of metals. Based on adsorption analysis is known that $\mathrm{Pb}$ (II) and $\mathrm{Cu}$ (II) is $\mathrm{Hg}$ (II) competitor while $\mathrm{Fe}$ (II) is not $\mathrm{Hg}$ (II) competitor in adsoption by using Sargassum crassifolium. On binary system in equimass amount of metals ion and equimolar amounts of metals that the largest decreasing effect of $\mathrm{Hg}$ (II) adsorption in system contain $\mathrm{Cu}(\mathrm{II})$.
\end{abstract}

Keywords: Sargassum crassifolium, $\mathrm{Hg}(\mathrm{II})$ adsorption, $\mathrm{Pb}(\mathrm{II}), \mathrm{Cu}(\mathrm{II}), \mathrm{Fe}(\mathrm{II})$

\section{PENDAHULUAN}

Kegiatan pertambangan dan industri dapat meningkatkan adanya logam berat yang toksik dan berpotensi mencemari lokasi dan lingkungan. Salah satunya adalah penambangan emas rakyat yang disebut penambangan emas tanpa izin (PETI) yang menggunakan merkuri sebagai pengikat unsur emas dalam proses amalgamsi. Pencemaran tersebut terjadi ketika sebagian merkuri yang digunakan sebagai bahan pengikat unsur emas terbuang bersama air limbah pencucian ke lokasi pembuangan baik di tanah maupun di air sungai (Setiyono dan Daijah, 2012).

Merkuri merupakan salah satu logam berat yang sangat beracun dan dapat terakumulasi pada air, tanah dan organisme. Merkuri dapat menyebabkan kerusakan otak, ginjal, sistem saraf, penglihatan dan pendengaran (WHO, 2017; Setyono dan Daijah, 2012; Sumantri et al,
2014). Oleh karena itu perlu dilakukan suatu cara untuk meminimalisasi polutan ion merkuri sehingga tidak berbahaya bagi lingkungan dan organisme. Menurut Kementrian Lingkungan Hidup (2004) dan Peraturan Pemerintah Republik Indonesia (2001), batas maksimum konsentrasi di lingkungan yaitu $0,005 \mathrm{mg} / \mathrm{L}$ untuk air limbah hasil penambangan dan 0,001 $\mathrm{mg} / \mathrm{L}$ untuk air minum.

Adsorpsi merupakan salah satu metode yang dapat digunakan untuk mengurangi kadar logam berat. Metode ini bergantung pada pemilihan jenis adsorben dan berbagai parameter dalam proses adsorpsi seperti keasaman, perbandingan adsorben dengan logam maupun keberadaan logam lain (Carro et al., 2011). Alga coklat terutama Sargassum termasuk jenis alga yang diketahui sebagai adsorben logam berat yang efektif. Selain itu alga coklat merupakan biomassa yang melimpah. 
Adsorpsi merkuri oleh berbagai spesies Sargassum seperti Sargassum cristaefolium, Sargassum sp dan Sargassum muticum telah diteliti dan kapasitas adsorpsi masing-masing yaitu $0,22 \mathrm{mmol} / \mathrm{g}, 0,41 \mathrm{mmol} / \mathrm{g}$ dan $1,2 \mathrm{mmol} / \mathrm{g}$ (Alcantara et al., 2007; Barriada et al., 2009; Carro et al., 2011). Selain itu kapasitas adsorpsi Sargassum crassifolium teraktivasi terhadap ion $\mathrm{Hg}$ (II) diketahui sebesar $2,90 \mathrm{mmol} / \mathrm{g}$ (Silalahi et al, 2012).

Pada air limbah hasil penambangan emas terdapat logam-logam berat lain selain logam merkuri baik yang dihasilkan oleh aktivitas manusia (non alami) maupun terdapat secara alamiah misalnya $\mathrm{Pb}$ (II), $\mathrm{Cu}$ (II) dan $\mathrm{Fe}$ (II). Ion logam tersebut dapat memberikan efek sinergis untuk meningkatkan penyerapan terhadap logam yang akan diadsorpsi atau berkompetisi pada sisi ikatan dan mengurangi interaksi antara adsorbat dengan logam yang akan diadsorpsi. Selain itu, ion logam lain juga dapat tidak memberikan efek pada ion logam yang akan diadsorpsi (Alcantara et al., 2007; Herero et al., 2005). Pada penelitian ini dilakukan adsorpsi $\mathrm{Hg}$ (II) dengan adanya ion logam lain sehingga diketahui efeknya terhadap adsorpsi logam $\mathrm{Hg}$ (II) menggunakan Sargassum crassifolium.

\section{METODOLOGI}

\section{Bahan}

Bahan-bahan yang digunakan adalah Sargassum crassifolium dari Perairan Pulau Lemukutan Kabupaten Bengkayang Kalimantan Barat, akuades, buffer $\mathrm{pH} 4$, buffer $\mathrm{pH} 7, \mathrm{HNO}_{3}$ pekat, $\mathrm{H}_{2} \mathrm{SO}_{4}$ pekat, kertas saring, padatan $\mathrm{CuNO}_{3}$, padatan $\left(\mathrm{NH}_{4}\right)_{2} \mathrm{Fe}\left(\mathrm{SO}_{4}\right)_{2}$, padatan $\mathrm{HgCl}_{2}$, padatan $\mathrm{NaOH}$ dan padatan $\mathrm{PbNO}_{3}$.

\section{Alat}

Alat-alat yang digunakan adalah alat-alat gelas standar, botol plastik $250 \mathrm{~mL}$, botol semprot, neraca analitik Ohaus PAJ 1003, oven, pH meter Hanna Instrument model 19208, rotary shaker Ikalabortechnik KS501 Digital, dan Spektrofotometer Serapan Atom (SSA) Shimadzu 6800 dan Perkin Elmer AA700.

\section{Prosedur Kerja \\ Preparasi Adsorben}

Sargassum crassifolium diambil dari Perairan Pulau Lemukutan, Kabupaten Bengkayang, Kalimantan Barat. Data mengenai $\mathrm{pH}$ dan kedalaman air dicatat. Sampel dibersihkan, dideterminasi dan dipreparasi menjadi adsorben (Silalahi et al., 2012).

\section{Adsorpsi $\mathrm{Hg}(\mathrm{II})$ Dengan Adanya $\mathrm{Cu}(\mathrm{II})$, $\mathrm{Pb}$ (II) dan Fe(II)}

Adsorpsi $\mathrm{Hg}(\mathrm{II})$ menggunakan Sargassum crassifolium dengn adanya $\mathrm{Pb}(\mathrm{II}), \mathrm{Cu}(\mathrm{II})$ dan $\mathrm{Fe}(\mathrm{II})$ terhadap dilakukan dengan sistem dua logam dan empat logam yang masing-masing bermassa logam sama dan bermolaritas yang sama. Sistem dua logam terdiri dari yaitu $\mathrm{Hg}$ (II) - $\mathrm{Pb}(\mathrm{II}), \mathrm{Hg}(\mathrm{II})-\mathrm{Cu}(\mathrm{II}), \mathrm{Hg}$ (II) - Fe(II) dan sistem empat logam terdiri dari campuran $\mathrm{Hg}$ (II) $-\mathrm{Pb}(\mathrm{II})-\mathrm{Cu}$ (II) $-\mathrm{Fe}(\mathrm{II})$.

Perlakuan logam bermassa sama adalah sebagai berikut: Sebanyak 0,1 gram adsorben dimasukkan ke dalam botol plastik yang berisi $140 \mathrm{~mL}$ larutan dengan sistem dua logam dan empat logam masing-masing dengan konsentrasi larutan $0,5 \mathrm{mg} / \mathrm{L}$ pada $\mathrm{pH} 7$. Kemudian diaduk dengan rotary shaker pada kecepatan $200 \mathrm{rpm}$ selama 60 menit. Selanjutnya didiamkan selama 15 menit. Larutan campuran logam yang telah diinteraksikan dengan adsorben dipisahkan dengan cara disaring. Konsentrasi $\mathrm{Hg}$ (II), $\mathrm{Cu}$ (II), $\mathrm{Pb}$ (II) dan $\mathrm{Fe}$ (II) dalam filtrat hasil penyaringan ditentukan menggunakan Spektrofotometer Serapan Atom (SSA). Semua perlakuan dilakukan secara duplo.

Perlakuan molaritas sama sebagai berikut: Sebanyak $0,1 \mathrm{~g}$ adsorben dimasukkan ke dalam botol plastik yang berisi masing-masing $140 \mathrm{~mL}$ larutan sistem dua logam dan empat logam dengan molaritas larutan 0,0025 mM pada $\mathrm{pH} 7$. Kemudian diaduk dengan rotary shaker pada kecepatan $200 \mathrm{rpm}$ selama 60 menit. Selanjutnya didiamkan selama 15 menit. Larutan yang telah diinteraksikan dengan adsorben dipisahkan dengan cara disaring. konsentrasi $\mathrm{Hg}$ (II), $\mathrm{Pb}$ (II), $\mathrm{Cu}$ (II) dan $\mathrm{Fe}$ (II) dalam filtrat hasil penyaringan ditentukan menggunakan Spektrofotometer Serapan Atom (SSA). Semua perlakuan dilakukan secara duplo.

$\%$ Logam Teradsorpsi $=\frac{\mathrm{Ci}-\mathrm{Cf}}{\mathrm{Ci}} \times 100 \%$

Ket: $\mathrm{Ci}$ : konsentrasi awal logam $(\mathrm{mg} / \mathrm{L})$,

$C f$ : konsentrasi akhir logam $(\mathrm{mg} / \mathrm{L})$

Data yang diperoleh dari hasil Spektrofotometer Serapan Atom yaitu konsentrasi $\mathrm{Hg}(\mathrm{II}), \mathrm{Pb}(\mathrm{II}), \mathrm{Cu}$ (II) dan $\mathrm{Fe}$ (II) yang teradsorpsi (selisih konsentrasi logam awal dan 
konsentrasi sisa dalam larutan logam). Persentase ion logam yang teradsorpsi dapat dihitung menggunakan Persamaan 1.

\section{HASIL DAN PEMBAHASAN}

Pada air limbah penambangan emas terdapat beberapa jenis logam lain selain merkuri. Hal ini disebabkan dalam bijih emas terdapat logam lain yang bercampur seperti logam timbal $(\mathrm{Pb})$, tembaga $(\mathrm{Cu})$ dan besi $(\mathrm{Fe})$. Berdasarkan data kadar logam di sekitar daerah tambang diketahui bahwa kadar logam $\mathrm{Pb}, \mathrm{Cu}, \mathrm{Fe}$ dan $\mathrm{Hg}$ berturutturut mencapai $0,114 \mathrm{mg} / \mathrm{L} ; 0,042 \mathrm{mg} / \mathrm{L} ; 34,6$ $\mathrm{mg} / \mathrm{L}$ dan $0,008 \mathrm{mg} / \mathrm{L}$.

Efek $\mathrm{Pb}(\mathrm{II}), \mathrm{Cu}(\mathrm{II})$ dan $\mathrm{Fe}(\mathrm{II})$ terhadap adsorpsi $\mathrm{Hg}(\mathrm{II})$ menggunakan Sargassum crassifolium dianalisis dengan membandingkan persentase logam yang teradsorpsi dalam sistem dua logam dan empat logam baik dengan massa sama maupun molaritas sama.

\section{Sistem Dua Logam}

Sistem dua logam adalah campuran dua ion logam yang terdiri atas $\mathrm{Hg}(\mathrm{II})$ dengan logam lain yaitu $\mathrm{Pb}(\mathrm{II}), \mathrm{Cu}(\mathrm{II})$ dan $\mathrm{Fe}(\mathrm{II})$ sehingga menjadi $\mathrm{Hg}$ (II)- $\mathrm{Pb}$ (II), $\mathrm{Hg}$ (II)-Cu(II) dan $\mathrm{Hg}$ (II)$\mathrm{Fe}(\mathrm{II})$. Sistem ini dilakukan dalam kondisi logam bermassa dan bermolaritas sama. Campuran sistem dua logam dapat mengindikasikan pengaruh langsung ion logam lain terhadap adsorpsi $\mathrm{Hg}(\mathrm{II})$ menggunakan Sargassum crassifolium.

Gambar 1 menunjukkan bahwa pada perlakukan logam bermassa dan logam bermolaritas sama penurunan adsorpsi merkuri pada Sargassum crassifolium diakibatkan oleh sistem yang mengandung ion $\mathrm{Cu}(\mathrm{II})$ dan $\mathrm{Pb}$ (II). Adsorpsi $\mathrm{Hg}(\mathrm{II})$ terendah diperlihatkan pada sistem yang mengandung $\mathrm{Cu}$ (II) pada kedua perlakuan. Sedangkan adsorpsi $\mathrm{Hg}(\mathrm{II})$ yang mengandung $\mathrm{Fe}$ (II) menunjukkan tidak adanya perubahan dalam persentase merkuri yang teradsorpsi. Hal ini mengindikasikan bahwa $\mathrm{Hg}$ (II) berkompetisi dengan $\mathrm{Pb}$ (II) dan $\mathrm{Cu}$ (II) dalam berikatan dengan situs aktif adsorben. Pada pH 7 spesi logam $(\mathrm{Pb}$ dan $\mathrm{Cu})$ berbentuk kation bebas $\mathrm{M}^{2+}$ sedangkan merkuri dominan berbentuk $\mathrm{Hg}(\mathrm{OH}) \mathrm{Cl}$ sehingga interaksi antara spesi logam dengan adsorben dipengaruhi oleh efek elektrostatik (Carro et al., 2011; Silalahi et al., 2012).

Penelitian Alcantara, et. al., (2005) menggunakan Sargassum cristaefolium mengadsorpsi $\mathrm{Hg}(\mathrm{II})$ dengan adanya logam $\mathrm{Cu}$ (II) dan $\mathrm{Fe}$ (III) dalam sistem dua logam dengan kedua perlakuan menunjukkan bahwa $\mathrm{Cu}$ (II) adalah kompetitor dengan afinitas yang kuat terhadap adsorben sedangkan Fe(III) bukan kompetitor dalam mengadsorpsi $\mathrm{Hg}(\mathrm{II})$.
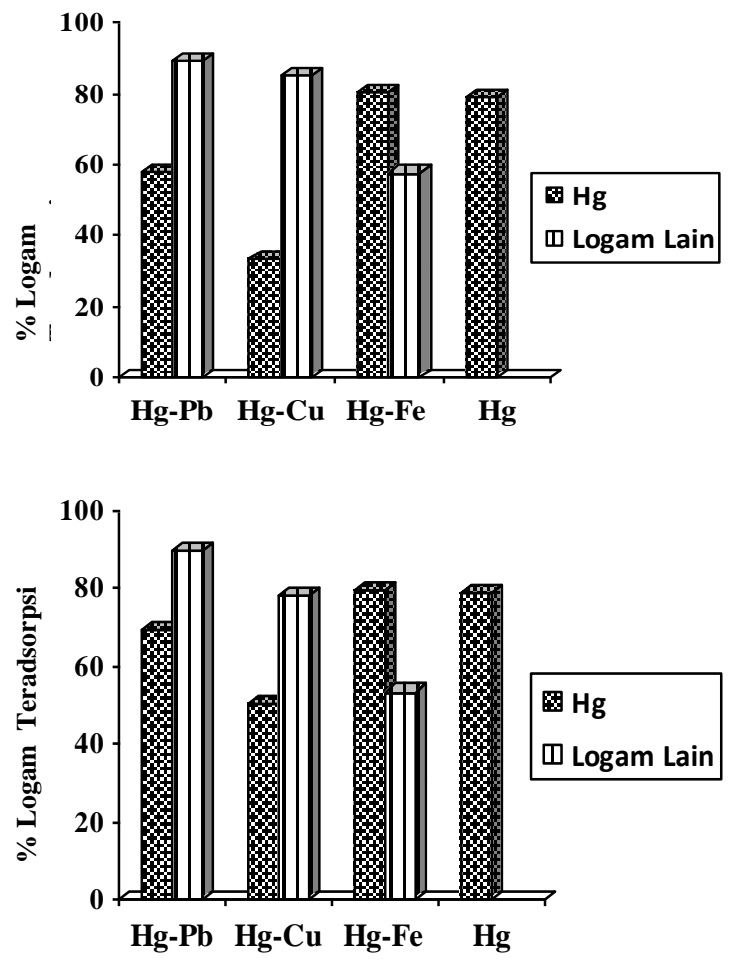

Gambar 1. Persentase (\%) logam yang teradsorpsi pada Sargassum crassifolium dalam sistem dua logam (a) Logam bermassa sama dan (b) Logam bermolaritas sama

Gambar 2 menunjukkan bahwa adanya pengaruh tiga logam yaitu $\mathrm{Pb}(\mathrm{II}), \mathrm{Cu}$ (II) dan $\mathrm{Fe}(\mathrm{II})$ terhadap adsorpsi $\mathrm{Hg}(\mathrm{II})$ baik pada perlakuan massa maupun molaritas sama. Persentase (\%) logam teradsorpsi yang tertinggi pada kedua perlakuan adalah $\mathrm{Pb}$ (II), diikuti oleh $\mathrm{Cu}$ (II), $\mathrm{Hg}$ (II) dan $\mathrm{Fe}(\mathrm{II})$. Fenomena ini diduga karena afinitas $\mathrm{Pb}(\mathrm{II})$ lebih besar dibandingkan dengan logam lain sehingga $\mathrm{Pb}(\mathrm{II})$ lebih teradsorpsi pada dinding sel alga. Afinitas $\mathrm{Pb}$ (II) lebih besar dibandingkan logam lain dipengaruhi oleh sifat ionik $\mathrm{Pb}$ (II) yang lebih dominan. Data ini juga menunjukkan bahwa interaksi antara gugus aktif adsorben dengan ion logam didominasi oleh interaksi ionik. $\mathrm{Cu}$ (II) yang teradsorpsi pada sistem empat logam pada massa dan molaritas logam yang sama memberikan hasil yang tidak jauh berbeda dengan $\mathrm{Pb}(\mathrm{II})$. 
Selain afinitas, ukuran ion logam juga mempengaruhi proses adsorpsi. Ukuran $\mathrm{Cu}$ (II) lebih kecil dibandingkan dengan logam lain $(\mathrm{Pb}$ (II), $\mathrm{Hg}$ (II) dan $\mathrm{Fe}(\mathrm{II}))$ sehingga $\mathrm{Cu}$ (II) lebih mudah berinteraksi dengan gugus aktif adsorben

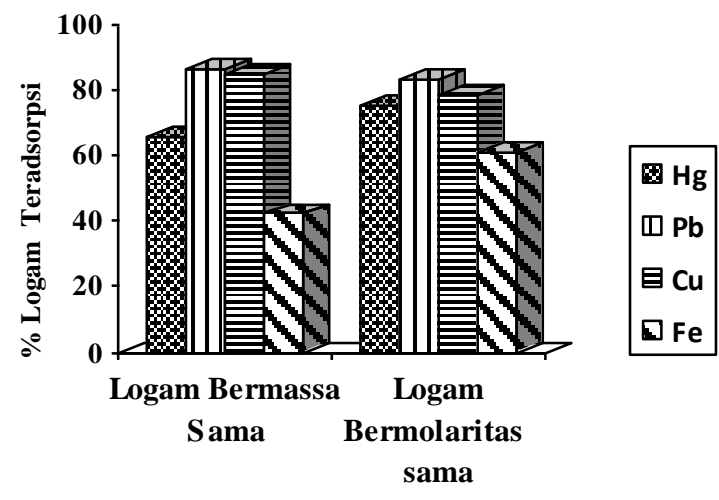

Gambar 2. Persentase (\%) logam yang teradsorpsi pada Sargassum crassifolium dalam sistem empat logam

Pada Fe(II) diperoleh kecenderungan yang sama baik pada sistem dua logam maupun sistem empat logam pada massa sama dan molaritas sama. Persentase (\%) Fe(II) teradsorpsi dalam kedua sistem lebih kecil dibandingkan dengan ion logam yang lain. Fenomena ini berarti ion $\mathrm{Fe}(\mathrm{II})$ memiliki afinitas paling rendah terhadap gugus aktif pada alga. Hal ini disebabkan ion $\mathrm{Fe}(\mathrm{II})$ bersifat sangat reaktif dan tidak stabil sehingga dapat teroksidasi menjadi ion $\mathrm{Fe}$ (III) yang cenderung membentuk endapan. Menurut hasil penelitian Alcantara et. al., (2005) ion $\mathrm{Fe}(\mathrm{III})$ dalam sistem dua atau empat logam tidak teradsorpsi dan memiliki afinitas terendah.

Persentase (\%) $\mathrm{Hg}(\mathrm{II})$ teradsorpsi dalam sistem dua logam dan empat logam pada logam bermassa sama lebih rendah dibandingkan dengan molaritas sama. Hal ini dipengaruhi oleh kerapatan partikel dalam larutan. Pada perlakuan logam bermassa sama kerapatan partikel lebih besar dibandingkan dengan perlakuan logam bermolaritas sama. Oleh karena itu, pada perlakuan logam bermassa sama efek kompetisi menjadi lebih besar karena jumlah ion logam lain lebih besar dibandingkan dengan perlakuan logam bermolaritas sama. Selain itu pada perlakuan massa efek tolakan antar logam lebih besar sehingga dapat membatasi adsorpsi ion Hg(II) (Mahamadi dan Nharingo, 2010).
Berdasarkan hasil analisis adsorpsi $\mathrm{Hg}$ (II) beserta logam lain diduga bahwa interaksi situs aktif dalam adsorben dengan logam didominasi oleh interaksi ionik sehingga adsorpsi $\mathrm{Hg}$ (II) tidak sebesar $\mathrm{Pb}$ (II) dan $\mathrm{Cu}$ (II). Hal ini dapat ditinjau dari sifat keasaman ion logam. Pada umumnya logam yang bersifat asam keras akan berinteraksi kuat dengan basa keras. Sebaliknya ion logam yang bersifat asam lunak kuat berinteraksi dengan basa lunak. Gugus aktif adsorben terdiri atas gugus karboksil, hidroksil yang bersifat basa keras dan gugus sulfonat yang bersifat basa madya (diantara basa keras dan basa lunak). Logam $\mathrm{Hg}$ (II) bersifat asam lunak sedangkan $\mathrm{Pb}$ (II) dan $\mathrm{Cu}$ (II) bersifat asam madya (diantara asam keras dan asam lunak). Hal tersebut menjelaskan bahwa ion $\mathrm{Pb}$ (II) dan $\mathrm{Cu}$ (II) akan lebih mudah terserap dibandingkan dengan ion $\mathrm{Hg}$ (II) dikarenakan pada $\mathrm{Pb}$ (II) dan $\mathrm{Cu}(\mathrm{II})$ perbedaan tingkat energi untuk membentuk ikatan dengan gugus aktif pada adsorben lebih kecil dibandingkan dengan $\mathrm{Hg}$ (II) sehingga $\mathrm{Pb}$ (II) dan $\mathrm{Cu}$ (II) lebih mudah berikatan dengan gugus aktif adsorben dibandingkan $\mathrm{Hg}(\mathrm{II})$.

\section{KESIMPULAN}

Adsorpsi $\mathrm{Hg}(\mathrm{II})$ menggunakan Sargassum crassifolium pada sistem dua logam pada logam bermassa sama dan bermolaritas sama diketahui bahwa $\mathrm{Cu}$ (II) dan $\mathrm{Pb}$ (II) bertindak sebagai kompetitor sehingga menurunkan adsorpsi $\mathrm{Hg}$ (II) sedangkan $\mathrm{Fe}$ (II) tidak mempengaruhi adsorpsi $\mathrm{Hg}$ (II) dimana efek penurunan adsorpsi $\mathrm{Hg}$ (II) terbesar dalam sistem yang mengandung $\mathrm{Cu}(\mathrm{II})$. Pada sistem empat logam pada logam bermassa sama dan bermolaritas sama diketahui bahwa $\mathrm{Pb}(\mathrm{II})$ lebih banyak teradsorpsi dibandingkan dengan $\mathrm{Hg}$ (II), $\mathrm{Cu}$ (II) dan $\mathrm{Fe}$ (II) yang dipengaruhi oleh afinitas dan ukuran logam.

\section{UCAPAN TERIMA KASIH}

Terima kasih kepada DIT.LITABMAS DIKTI yang telah menyediakan dana penelitian ini.

\section{DAFTAR PUSTAKA}

Alcantara, R.T., Apodaca, D.C., De Guzman, M.R., 2007, The Effect of the Presence of $\mathrm{Cu}^{2+}$ and $\mathrm{Fe}^{3+}$ Metal Ions on the Sorption of 
Nurhadini dkk. / Indo. J. Chem. Res., 2017, 5(1), 7-11

Mercuric Ion $\left(\mathrm{Hg}^{2+}\right)$ by Sargassum cristaefolium. A. J. Ch. E., 7: 147-156

Barriada, J.L., Carro, L., Herrero, R., de Vicente, M.E., 2009, Mercury removal: a physicochemical study of metal interaction with natural materials, J. Chem. Technol. Bio, 11: $1688-1696$

Carro, L., Barriada, J.L., Herrero, R., de Vicente, M.E., 2011. Adsorptive behaviour of mercury on algal biomass: Competition with divalent cations and organic compounds, Journal of Hazardous Materials, 192: 284291.

Kementrian Lingkungan Hidup, 2004, Keputusan Menteri Negara Lingkungan Hidup Tentang Baku Mutu Air Limbah Bagi Usaha Dan Pertambangan Bijih Emas atau Tembaga, Jakarta.

Mahamadi, C., Nharingo, T., 2010, Competitive adsorption of $\mathrm{Pb}^{2+}, \mathrm{Cd}^{2+}$ and $\mathrm{Zn}^{2+}$ ions onto Eichhornia crassipes in binary and ternary system. Bioresource Technology,101: 859864
Peraturan Pemerintah, 2001, Peraturan Pemerintah Republik Indonesia Nomor 82 Tentang Pengelolaan Kualitas Air Dan Pengendalian Pencemaran Air, Jakarta.

Silalahi, I.H., Zahara, T.A., Tampubolon, H.M., 2012, Kapasitas Adsorpsi Menggunakan Sargassum crassifolium, Biopropal Industri, 3: $28-38$

Setiyono, A., Daijah, A., 2012, Pengaruh Konsumsi Ikan dan Hasil Pertanian Terhadap Kadar Hg Darah, Jurnal Kesehatan Masyarakat, 7: 104-110.

Sumantri, A., Laelasari, E., Junita, N.R., Nasrudin, 2014, Logam Merkuri pada Pekerja Penambangan Emas Tanpa Izin, Jurnal Kesehatan Masyarakat, 8398 - 403.

World Health Organization, 2017, Mercury and Health, www.who.int, Diakses tanggal 10 Agustus 2017. 